\section{Current strategy for leprosy control in Brazil: time to pursue alternative preventive strategies?}

\author{
Sérgio S. Cunha, ${ }^{1,2}$ \\ Laura C. Rodrigues, ${ }^{1}$ \\ and Nádia Cristina Duppre ${ }^{3}$
}

\section{CURRENT STRATEGY FOR PREVENTING LEPROSY IN BRAZIL}

Leprosy is closely related to living conditions and poverty. Although Brazil is a middle-income country, the distribution of wealth in this society remains unequal (at 60.7, Brazil's Gini coefficient is the sixth highest in the world. 7). Large sectors of the population live in poverty, and almost a quarter of the population lives on an income of less than US\$ 2 a day (1). In Brazil 38365 new cases of leprosy were recorded in 2002, corresponding to a new case detection rate of 22.3 per 10000 , the tenth highest in the world (2). The rate of detection of leprosy in the last 20 years has increased in many areas in the country $(3,4)$, and studies have shown an association between poverty and leprosy in $\operatorname{Brazil}(5,6)$.

The current strategy for the control of leprosy in Brazil is based on two major activities: 1) early case detection and 2) treatment of all cases with multidrug therapy (MDT). Tracing of household contacts for early diagnosis and Bacille CalmetteGuérin (BCG) vaccination is a third, complementary measure recommended by the Ministry of Health but not implemented everywhere. In addition, Leprosy Elimination Campaigns (7) have been used to promote MDT usage.

\section{EARLY CASE DETECTION AND MULTIDRUG THERAPY}

The World Health Organization (WHO) defends the position that early case detection and treatment of leprosy with MDT will lead to the elimination of leprosy by quickly rendering persons noninfectious (8). However, it is not known to what extent the prevalence of leprosy needs to be reduced to lead to a reduction in the incidence of the disease. Likewise, it is not known whether the incidence can be reduced when the prevalence is below 1 per 10000 (9). Furthermore, evidence that MDT reduces the incidence of leprosy is lacking, and it is not easy to disentangle the effects of policies based on MDT from other confounding factors (10). This has nurtured a lively debate in the literature, with arguments against the expectation that MDT will reduce the incidence of leprosy (11). The belief that leprosy can be eliminated with this strategy is based on hypothesis rather than on evidence. Con- 
sidering that the impact of a leprosy control program is also determined by its coverage, by operational factors (12) and by the existence of hidden cases, it is doubtful that control based mainly on case detection and treatment will have an impact. on the incidence of leprosy. Therefore, it is questionable whether leprosy can be eliminated through case detection and treatment in Brazil.

\section{CONTACT TRACING AND BCG VACCINATION OF CONTACTS}

Contact tracing is done for two reasons. First, clinical examination of contacts aims to detect cases of leprosy in earlier stages of the disease, before the patient develops deformities and disabilities. However, there is no consensus in the literature on the extent to which the early administration of MDT prevents disability, as irreversible tissue lesions can be present before diagnosis and MDT, and can progress after treatment is started (13). Second, BCG vaccination of household contacts (14) aims to reduce the number of new cases in the household of contacts. But the impact of BCG vaccination on the control of leprosy in this subpopulation hinges on two questions: whether BCG vaccination of contacts is protective, and what proportion of all cases can thus be prevented.

Regarding whether BCG vaccination of contacts is protective, household contacts are at a higher risk of getting the disease, so BCG vaccination would be beneficial if it reduced their risk. The ability of the BCG vaccine to protect against leprosy has been consistently shown in several studies, but the estimates of protection have varied widely ( $20 \%$ to $90 \%)(15,16)$. The only vaccine study in which the study population received BCG as part of a program for the vaccination of contacts was a case-control study conducted in Venezuela (17), which showed a protection rate of $56 \%$ (95\% CI: $27 \%$ to $74 \%$ ). However, part of the study population also received BCG as part of a tuberculosis control program, i.e., before becoming contacts. In Brazil, among the contacts of leprosy patients, most children would have received neonatal BCG, whereas most adults would not have. All studies conducted in contacts in Brazil estimated the protection offered by neonatal BCG vaccination $(16,18,19)$. An ongoing cohort study that aims to assess the protection afforded by BCG vaccine in the context of vaccination of contacts in Brazil (20) will offer more conclusive evidence.

The second question is whether vaccination of contacts, even if it offers protection to contacts, will have a significant impact on the incidence of leprosy overall. This will depend on the proportion of the total number of cases of leprosy that arise from household contacts (21). In general, only a minority of all cases of leprosy in the community arises from recognizable household contacts. Earlier studies have noted that $20 \%$ to $30 \%$ of all cases occur in contacts $(22,23)$. In this setting, even a highly protective vaccine with a very high coverage rate among household contacts might prevent no more than one third of all cases of leprosy.

There is evidence that the risk of disease decreases rapidly among household contacts from the moment when the index case is detected and contact tracing is started (19). This suggests that maximum protection would be achieved if BCG elicited protection soon after vaccination. However, an increase in the risk of leprosy with BCG vaccination has been described in the initial follow-up in some trials (24). If this occurs, the protection conferred by vaccination may start too late to prevent cases among contacts.

Therefore, what impact can we expect from BCG vaccination among contacts in Brazil? Despite the fact the vaccination of contacts is officially recommended in Brazil and has been practiced for several years, the impact of vaccination on the incidence of leprosy in the community as a whole has not been measured, and its cost-effectiveness has not been evaluated.

\section{THE CASE FOR ALTERNATIVE STRATEGIES}

The doubts regarding the impact of current strategies raise the question of whether alternative preventive measures should be implemented. There are at least two alternative approaches which have not yet been assessed in Brazil. One approach is to attempt to maximize the impact of current BCG vaccination of contacts and to extend contact tracing by increasing the number of people defined as a contact and then vaccinated. Surveys found a much higher proportion of cases with a history of contact when a broader definition of contact was used $(23,25)$. This suggests that transmission of leprosy occurs in "concentric circles around a patient" (26), as in tuberculosis. If a higher proportion of cases comes from contacts outside the household, it may be possible to maximize the impact of contact tracing by expanding it to include individuals who are not household members but are still at an increased risk of developing leprosy (e.g., neighbors and social contacts). A broader definition of contacts would increase the population-attributable fraction for contact status, and hence the populationpreventable fraction for preventive measures among contacts. 
The second alternative approach is chemoprophylaxis. There is evidence from most studies of contacts that chemoprophylaxis may reduce the incidence of leprosy (27). However, the impact of this measure depends on the duration of its effect and on whether it is used in the general population or among those at increased risk as part of contact tracing. In the latter case, the impact on the general population will depend on the proportion of contacts that receive timely chemoprophylaxis.

Finally, new tests have been developed to identify high-risk groups $(23,28)$, and it may thus be possible to identify people at high risk of developing leprosy who are not household contacts. The program for family health currently operating in many sites in Brazil, and its integration with the leprosy control program, may make it possible to use screening and to adopt a broader definition of contacts. This may result in the expansion of tracing efforts to include persons at high risk in vaccination or chemoprophylaxis programs.

Another neglected issue is the impact of neonatal BCG vaccination, which has been implemented routinely to prevent tuberculosis. There is accumulating evidence that neonatal BCG vaccination confers a high degree of protection against leprosy $(16,18,19)$. Neonatal BCG in Brazil had reached coverage rates of $90 \%$ by the late 1990 s, thus most Brazilians up to the age of 10 to 15 years will have some protection against leprosy. This policy has advantages over vaccination of contacts because vaccination is given before exposure to an index case. Neonatal BCG may have had an important impact in reducing leprosy in areas where coverage is high; this impact might be increasing as the cohort for which coverage of BCG is high reaches the age when the incidence of leprosy is high and replaces the previous generation.

In light of the above discussion, it seems that there is still room to pursue alternative approaches for leprosy control in addition to the widespread use of MDT, early case detection with active case finding, and prevention and treatment of disabilities. We suggest that the Brazilian leprosy control program should consider ensuring a high coverage rate for neonatal BCG vaccination in areas where the incidence of leprosy is high. We also suggest that the program should promote policy-oriented studies of the effectiveness, feasibility, and impact of more proactive alternative strategies. Some possible alternative approaches are:

1. assessing the impact of vaccination among contacts on the incidence in the whole population;

2. assessing the impact of identifying high-risk groups with a broader definition of leprosy con- tacts, with new diagnostic tools, or with both measures, in contact tracing aimed at vaccination, earlier case detection, and chemoprophylaxis;

3 . assessing the feasibility and impact of chemoprophylaxis in contacts and in areas where the incidence of leprosy is high;

4. evaluating the health impacts and economic costs of alternative strategies before they are widely recommended.

Acknowledgments. The first author (SSC) received support from the Fundação Coordenação de Aperfeiçoamento de Pessoal de Nivel Superior (CAPES), Brasilia, Brasil.

\section{SINOPSIS}

\section{Estrategia actual para el control de la lepra en Brasil: ¿es hora de investigar otras estrategias de prevención?}

La estrategia actual para el control de la lepra en Brasil se basa en dos actividades principales: la detección precoz de casos y el tratamiento de casos con farmacoterapia combinada. Además de dichas medidas, se realizan esfuerzos complementarios para identificar los contactos domésticos para el diagnóstico precoz y la vacunación con el bacilo de Calmette-Guérin (BCG). Sin embargo, la eficacia de estas acciones a la hora de reducir la incidencia de la lepra es aún discutible. Esto genera dudas acerca de la factibilidad de eliminar la lepra en Brasil e indica que deberían adoptarse otras medidas de prevención. A pesar del hecho de que la vacunación de los contactos se practica desde hace varios años, falta información sobre el impacto de esta medida sobre la incidencia de la lepra en la comunidad. Además, con frecuencia no se tiene en cuenta el impacto de la vacunación neonatal con la vacuna BCG. Sostenemos que hay lugar para la investigación de métodos alternativos en el control y recomendamos que el programa brasileño de control haga un seguimiento esmerado de las tasas de cobertura para la vacunación neonatal en aquellas zonas donde la lepra es endémica, con el fin de lograr que la cobertura siga siendo elevada. Además, recomendamos la realización de estudios, orientados hacia el desarrollo de politicas, sobre la eficacia, factibilidad e impacto de estrategias alternativas más previsoras. Algunos posibles temas para estos estudios serían: 1) el impacto de la vacunación de contactos sobre la incidencia de la enfermedad en la población en general, 2) la factibilidad y el impacto de la quimioprofilaxis, y 3) el impacto de la identificación de grupos de alto riesgo (o mediante la adopción de una definición amplia de los contactos expuestos a la lepra, o mediante la creación de nuevas herramientas diagnósticas), y del diseño de programas para la detección precoz y la administración de farmacoterapia combinada específicamente para estos grupos. 


\section{REFERENCES}

1. United Nations Development Programme. Human Development Report 2003. Available from: www.undp.org/ hdr2003. Accessed 4 July 2003.

2. World Health Organization. Global leprosy situation-Leprosy situation in Americas. 2003. Available from http:// www.who.int/lep/stat2002/Americas 02.htm. Accessed 30 June 2004

3. Cunha SS, Rodrigues LC, Moreira S, Carvalho LC, Barreto ML, Dourado I. Upward trend in the rate of detection of new cases of leprosy in the State of Bahia, Brazil. Int J Lepr 2001;69:308-17.

4. Figueiredo IA, Silva AAM. Aumento na detecção de casos de hanseníase em São Luiz, Maranhão, Brazil, de 1993 a 1998. A endemia está em expansão? [Increase in leprosy detection rates in São Luiz, Maranhão, Brazil, from 1993 to 1998. Is the endemic expanding?]. Cad Saúde Pública 2003:19:439-45.

5. Kerr-Pontes LR, Montenegro AC, Barreto ML, Werneck GL, Feldmeier H. Inequality and leprosy in Northeast Brazil: an ecological study. Int J Epidemiol 2004;33:262-9.

6. Martelli CM, Moraes Neto OL, Andrade AL, Silva SA, Silva IM, Zicker F Spatial patterns of leprosy in an urban area of central Brazil. Bull World Health Organ 1995;73(3):315-9.

7. WHO. Guidelines for carrying out leprosy elimination campaigns 1996. WHO Action Programme for the Elimination of Leprosy. Lepr Rev 1999;70:408-27.

8. World Health Organization. The Final Push Strategy to Eliminate Leprosy as a Public Health Problem. Questions and Answers. 2002. Available from: http:// www.who.int/lep/Elimination/ Elimination0.htm. Accessed 22 August 2003.

9. Meima A, Richardus JH, Habbema JD. Trends in leprosy case detection worldwide since 1985 . Lepr Rev 2004; 75:19-33.

10. Groenen G. Trends in prevalence and case finding in the ALERT leprosy control programme, 1979-1999. Lepr Rev 2002;73:29-40.

11. Lockwood DN. Leprosy eliminationa virtual phenomenon or a reality? $\mathrm{Br}$ Med J 2002;22:1516-8.

12. Motta $C P$, Zuniga M. Time trends of Hansen's disease in Brazil. Int J Lepr Other Mycobact Dis 1990;58(3):453-61.

13. Technical Forum of the International Leprosy Association. Prevention of disabilities and rehabilitation. Lepr Rev 2002;73:S35-43.

14. Brasil, Ministério da Saúde. Hanseniase. Vigilância Epidemiológica de Doenças e Agravos Específicos. In: Vigilância Epidemiológica de Doenças e Agravos Específicos; 2001. Available from: http:// www.funasa.gov.br/pub/GVE/GVE05 13A.htm. Accessed 20 July 2003.

15. Fine PE. Primary prevention of leprosy. Int J Lepr Other Mycobact Dis 1996;64 (4 Suppl):S44-9.

16. Lombardi C, Pedrazzani ES, Pedrazzani JC, Filho PF, Zicker F. Protective efficacy of BCG against leprosy in Sao Paulo. Bull Pan Am Health Organ 1996;30(1): 24-30.

17. Convit J, Smith PG, Zuniga M, Sampson C, Ulrich M, Plata JA, et al. BCG vaccination protects against leprosy in Venezuela: a case-control study. Int J Lepr Other Mycobact Dis 1993;61(2): 185-91.

18. Rodrigues ML, Silva SA, Neto JC, de Andrade AL, Martelli CM, Zicker F. Protective effect of intradermal BCG against leprosy; a case-control study in central Brazil . Int J Lepr Other Mycobact Dis 1992;60(3):335-9.

19. Matos H, Duppre N, Alvin M, Vieira L, Sarno E, Struchiner C. Epidemiologia da hanseníase em coorte de contatos in- tradomiciliares no Rio de Janeiro (19871991). Cad Saúde Publica 1999;15:533-42.

20. Duppre N, Sales JAC, Pereira AM, Matos H, Sarno EN. BCG revaccination on leprosy contacts: preliminary results. Int J Lepr Other Mycobact Dis 2002;70: 166A.

21. Noordeen SK. Prophylaxis - scope and limitations. Int J Lepr Other Mycobact Dis 2001;69:S16-20.

22. Fine PE, Sterne JA, Ponnighaus JM, Bliss L, Saui J, Chihana A, et al. Household and dwelling contact as risk factors for leprosy in northern Malawi. Am J Epidemiol 1997;146(1):91-102.

23. Bakker MI, Hatta M, Kwenang A, Klatser PR, Oskam L. Epidemiology of leprosy on five isolated islands in the Flores Sea, Indonesia. Trop Med Int Health 2002;7:780-7.

24. Gupte MD, Vallishayee RS, Anantharaman DS, Nagaraju B, Sreevatsa, Balasubramanyam $\mathrm{S}$, et al. Comparative leprosy vaccine trial in south India. Indian J Lepr 1998;70(4):369-88.

25. van Beers SM, Hatta M, Klatser PR. Patient contact is the major determinant in incident leprosy: implications for future control. Int J Lepr Other Mycobact Dis 1999;67(2):119-28

26. Klatser PR. Strategies for pro-active case-finding in leprosy control. Int J Lepr 2001;69:S30-2.

27. Smith CM, Smith WCS. Chemoprophylaxis is effective in the prevention of leprosy in endemic countries: a systematic review and meta-analysis. J Infect 2000; 41:137-42.

28. Buhrer-Sekula S, Smits HL, Gussenhoven GC, Van Leeuwen J, Amador S, Fujiwara T, et al. Simple and fast lateral flow test for classification of leprosy patients and identification of contacts with high risk of developing leprosy. J Clin Microbiol 2003;41:1991-5.

The greatest discovery of my generation is that a human being can alter his life by altering his attitudes of mind.

\section{[El mayor descubrimiento de mi generación es que un ser humano puede cambiar su vida cambiando su actitud mental.]}

